\title{
Kaji Eksperimental Pengaruh Pemasangan Photovoltaic Pada Dinding Bangunan Terhadap Temperatur Ruangan
}

\author{
M. Dyan Susila ${ }^{1}$, A. Yudi Eka Risano ${ }^{1}$, Mei Hartanto ${ }^{1}$ \\ ${ }^{1)}$ Dosen Jurusan Teknik Mesin, Fakultas Teknik Universitas Lampung \\ Jl. Soemantri Brojonegoro No. 1 Bandar Lampung 35145 \\ Email : meyhartanto@yahoo.com
}

\begin{abstract}
Abstrak
Daerah perkotaan banyak sekali gedung bertingkat baik untuk perkantoran maupun pusat bisnis, dengan model dinding beton maupun kaca. Bagian bangunan secara umum mendapat sinar matahari baik secara bergiliran maupun terus menerus sepanjang siang hari. Penyinaran tanpa hambatan ini akan meningkatkan kalor yang masuk ke dalam ruangan dan beban pendingin ruangan akan meningkat, sehingga konsumsi energi listrik juga akan bertambah. Salah satu upaya mengatasinya dengan pemasangan photovoltaic. Untuk mengetahui pengaruh pemasangan PV terhadap temperatur ruangan dilakukan kajian eksperimental dengan mensimulasikan intensitas berasal dari cahaya lampu ultrasonik. Penelitian ini dilakukan pada model bangunan, dimana PV dipasang pada dinding dengan sudut pemasangan $15^{\circ}$ dan posisi lampu penyinaran dengan sudut $0^{\circ}$, $30^{\circ}$, dan $60^{\circ}$. Parameter yang diuji adalah temperatur $P V$, temperatur luar dan dalam dinding serta temperatur ruangan. Hasil pengujian ini akan dibandingkan dengan variasi intensitas cahaya lampu yakni 500 watt dan 1000 Watt. Hasil penelitian memperlihatkan bahwa pemasangan PV pada dinding bangunan dapat memperlambat kenaikan temperatur ruangan. Pemasangan PV dengan posisi miring, memberikan pengaruh positif terhadap pengurangan laju pemanasan ruangan.
\end{abstract}

Kata Kunci: photovoltaic, temperatur, intensitas cahaya

\section{PENDAHULUAN}

Energi surya merupakan salah satu energi baru dan terbarukan yang masih sedikit dimanfaatkan. Berdasarkan blueprint pengelolaan energi nasional 2006 - 2025, pada tahun 2025 produksi energi dari energi surya, biomassa, air dan nuklir baru mencapai angka 5\% [1]. Direncanakan tahun 2014 kapasitas terpasang Pembangkit Listrik Tenaga Surya (PLTS) sudah mencapai 2 GWatt [2]. Sementara itu berdasarkan letak geografis Indonesia yang berada pada daerah katulistiwa, maka potensi energi surya yang dimiiki sangat besar. Intensitas radiasi matahari di Indonesia mencapai 4,8 $\mathrm{kWh} / \mathrm{m} 2 /$ hari dengan waktu efektif penyinaran $8-10 \mathrm{jam} /$ hari [3].

Indonesia yang merupakan daerah tropis selain menguntungkan dalam potensi sumber energi surya, juga menjadi persoalan dalam mendapatkan kenyamanan termal ruangan. Radiasi matahari yang masuk ke dalam ruangan melalui dinding dan kaca jendela menambah energi termal dalam ruangan. Untuk mendapatkan kenyamanan termal ruangan, penggunaan sistem pengondisian udara (air conditioning/AC) menjadi kebutuhan yang tidak dapat terelakkan. Peningkatan penggunaan. AC terutama pada sektor publik seperti; perkantoran, rumah sakit, hotel, dan pusat perbelanjaan mengakibatkan terjadinya peningkatan kebutuhan energi listrik. Penggunaan energi listrik untuk sektor AC pada gedung menurut penelitian Puslitbang Permukiman SDA Kementerian PU tahun 2010 mencapai 65\% [4]. Penelitian JICA 2008, memperlihatkan bahwa penggunaan energi listrik untuk AC cukup besar yakni, 38,99\% untuk R1- 1300VA, 36,84\% untuk R1-2200VA, dan 47,66\% untuk R24400VA. Sedangkan untuk bangunan komersil persentase energi listrik yang digunakan adalah sebagai berikut; hotel $65 \%$, rumah sakit $57 \%$, Mall/pusat perbelanjaan $57 \%$, kantor pemerintah $55 \%$, dan bangunan kantor $47 \%$ [5].Untuk tidak terjadi pemborosan listrik, pemerintah mengeluarkan kebijakan penghematan pemakaian listrik yang tertuang dalam Instruksi Presiden No.13 tahun 2011 tentang penghematan energi dan air [6].

Dinding bangunan bertingkat biasanya mendapat penyinaran langsung dari matahari. Lamanya mendapatkan penyinaran sesuai dengan posisi geografis bangunan. Energi matahari yang menyinari bangunan dapat dijadikan sumber energi bagi bangunan dengan memasang photovoltaic (PV) pada dinding 
bangunan tersebut. Disisi lain pennyinaran langsung dari matahari akan mengakibatkan panas radiasi masuk ke dalam bangunan sehingga beban pendinginan akan meningkat. Radiasi matahari yang diterima permukaan dinding bagian luar ada yang diserap menjadi panas dan ada juga yang dipantulkan kembali, seperti terlihat pada gambar 1 . Besar energi yang diserap dan dipantulkan tergantung pada sudut datang radiasi matahari terhadap dinding. Selain itu besar energi panas yang dihasilkan dari radiasi matahari dipengaruhi oleh derajat kehitaman permukaan. Energi yang diserap oleh dinding dalam bentuk energi panas ada yang diteruskan secara konduksi ke permukaan dalam dinding dan ada juga yang diambil udara secara konveksi Laju perpindahan panas pada dinding dipengaruhi oleh konduktivitas termal bahan. Panas yang sampai pada permukaan dinding bagian dalam akan berpindah secara konveksi dan radiasi. Semakin besar energi panas yang masuk ke dalam ruangan maka semakin tinggi temperatur ruangan tersebut. Pemasangan PV pada dinding vertikal selain menghasilkan energi listrik diharapkan dapat mengurangi rambatan panas ke dalam ruangan. Penelitian ini bertujuan melihat pengaruh posisi pemasangan PV pada dinding bangunan terhadap temperatur ruangan.

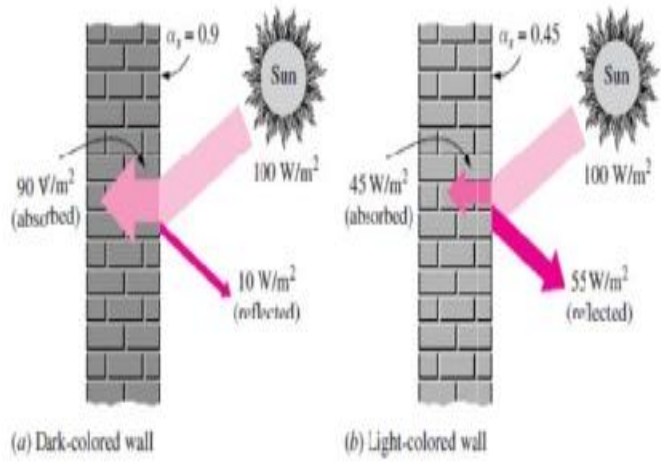

Gambar 1. Perpindahan panas dari radiasi matahari ke dalam ruangan melewati dinding [7]

\section{METODOLOGI}

Penelitian ini dilakukan secara eksperimental pada model bangunan dengan dinding yang dikenakan cahaya yang berasal dari lampu halogen 500 Watt dan 1000 Watt sebagai pemodelan cahaya matahari. Pengujian dilakukan dengan memvariasikan intensitas cahaya, hal ini diperoleh dengan cara mengubah sudut penyinaran yaitu dengan sudut $0^{\circ}, 30^{\circ}, 60^{\circ}$. Dinding dibuat dari bata merah yang sudah di plester dan diaci sisi luar dan dalam serta dicat dengan cat tembok warna putih. Ukuran bangunan adalah $41 \mathrm{~cm} \times 43 \mathrm{~cm} \times 43 \mathrm{~cm}$. dinding selain dinding uji diberi isolasi. Pemodelan photovoltaic yang diuji dengan ukuran $43 \mathrm{~cm}$ x $41 \mathrm{~cm}$, dengan daya output 20 Watt. Alat ukur temperatur menggunakan termometer Luthron dengan sensor termokopel tipe K. Toleransi alat ukur $0.01{ }^{0} \mathrm{C}$. Termokopel ditempatkan pada permukaan luar PV, permukaan luar dan dalam dinding, serta ditengah-tengah ruangan. Skema alat uji terlihat pada gambar 2. Pengujian dilakukan dengan memvariasikan sudut lampu $(\beta)$ yakni; $0^{\circ}, 30^{\circ}$, dan $60^{\circ}$, serta sudut PV $(\alpha)$ yakni $15^{\circ}$. Pada masing-masing posisi tersebut dilakukan pengujian selama 5 jam. Dari data ini akan dianalisa pengaruh pemasangan PV pada dinding terhadap laju perubahan temperatur ruangan.

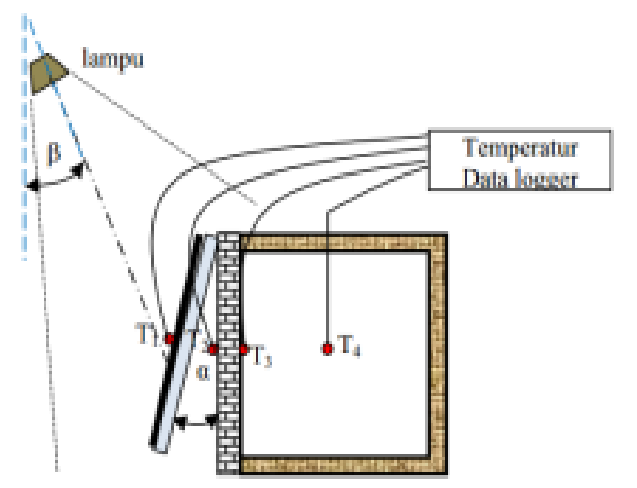

Gambar 2. Skema alat uji penggunaan PV pada dinding bangunan

\section{HASIL DAN PEMBAHASAN}

Perbedaan intensitas dilihat dari lampu yang digunakan dalam pengujian yaitu lampu 500 Watt dan 1000 Watt. Intensitas maksimal diperoleh jika sudut penyinaran antara lampu terhadap PV adalah tegak lurus. Semakin besar intensitas cahaya lampu maka semakin besar temperatur yang masuk ke ruangan. Data perubahan temperatur digunakan untuk menghitung laju perpindahan panas. Pada PV diberikan kemiringan atau ruang udara sebesar $15^{0}$ yang dilambangkan dengan simbol $\alpha$. Ruang ini dihitung dari jarak PV ke tembok. Kemudian pada lampu pengganti intensitas matahari diberikan variasi sudut sebesar $0^{\circ}, 30^{\circ}$, dan $60^{\circ}$ yang disimbolkan dengan simbol $\beta$. Sudut ini diambil dari sinar datang yang tegak lurus 
dengan tanah secara horizontal.

Hubungan Intensitas Cahaya Lampu ( $\left.I_{r}\right)$ dengan Temperatur Ruangan $\left(T_{4}\right)$

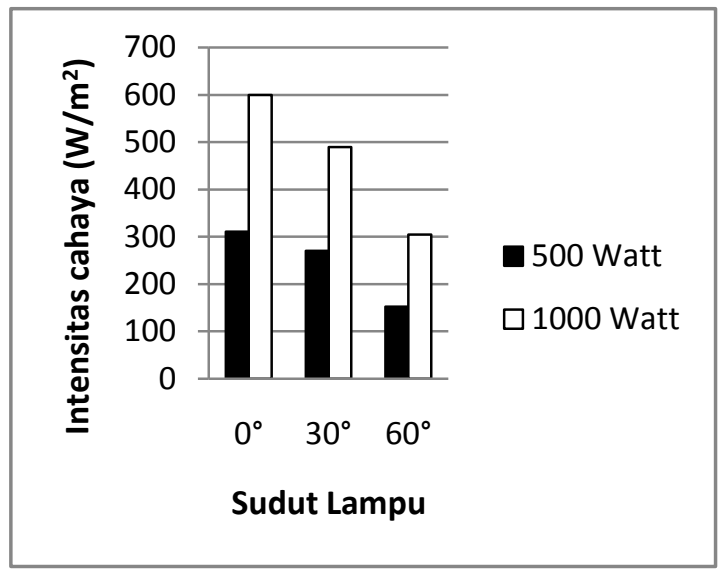

(a)

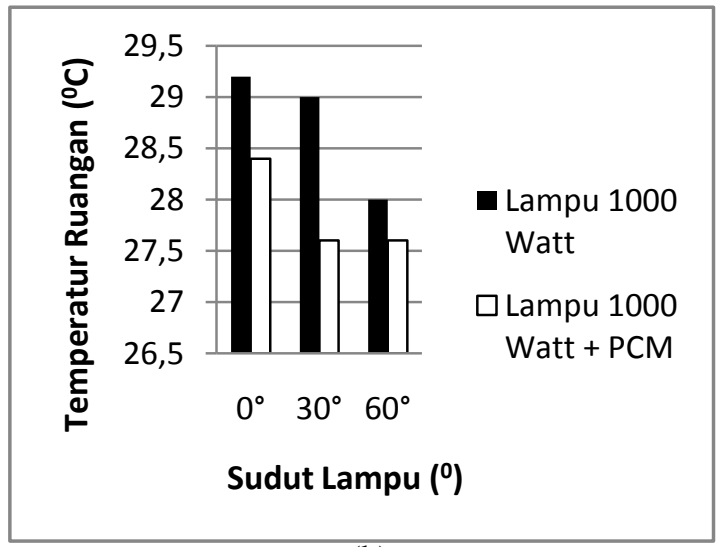

(b)

Gambar 3 (a). Diagram Hubungan Sudut Lampu dengan Intensitas Cahaya, (b) Diagram Hubungan

Sudut Lampu dengan Temperatur Ruangan

Berdasarkan gambar 3(a) intensitas cahaya dengan daya lampu 1000 Watt lebih besar dibandingkan dengan daya lampu 500 Watt. Hasil pengukuran intensitas cahaya lampu dengan daya 1000 watt pada sudut lampu $0^{0} \mathrm{I}_{\mathrm{r}}=$ $600 \mathrm{~W} / \mathrm{m}^{2}$, sedangkan pada lampu 500 Watt $\mathrm{I}_{\mathrm{r}}=$ $311,2 \mathrm{~W} / \mathrm{m}^{2}$. Dapat disimpulkan bahwa semakin kecil sudut lampu maka semakin besar intensitas cahaya lampu yang dihasilkan.

Berdasarkan gambar 3(b) temperatur ruangan pada lampu 500 Watt dan 1000 Watt dengan sudut lampu $0^{0}$ lebih besar dibandingkan sudut lampu $30^{\circ}$ dan $60^{\circ}$. Hai ini menunjukkan bahwa hubungan antara intensitas cahaya lampu dengan temperatur ruangan adalah berbanding lurus.

Hubungan Intensitas Cahaya Lampu ( $\left.I_{r}\right)$ dengan Laju Perpindahan Panas (q)

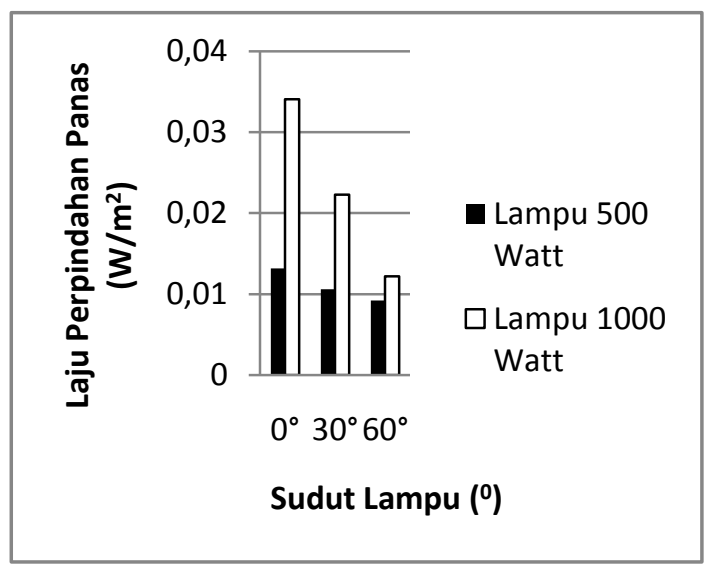

Gambar 4. Diagram Hubungan antara Intensitas Cahaya Lampu dengan Laju Perpindahan Panas

Pada lampu 1000 Watt sudut lampu $0^{0}$ dengan $I_{r}=600 \mathrm{~W} / \mathrm{m}^{2}$ laju perpindahan panas yang terjadi sebesar $0.0341 \mathrm{~W} / \mathrm{m}^{2}$. Hasil ini lebih besar dibandingkan dengan sudut lampu $30^{\circ}$ dan $60^{\circ}$, karena intensitas terbesar dihasilkan pada sudut lampu $0^{0}$. Hal ini juga terjadi pada lampu 500 Watt sudut lampu $0^{0}$ dengan $\mathrm{I}_{\mathrm{r}}=311.2$ $\mathrm{W} / \mathrm{m}^{2}$ yang menghasilkan laju perpidahan panas sebesar $0.0132 \mathrm{~W} / \mathrm{m}^{2}$. Dapat disimpulkan bahwa semakin besar intensitas cahaya lampu maka semakin besar pula laju perpindahan panasnya. 


\section{Pengaruh Penggunaan PCM Terhadap Temperatur Ruangan}

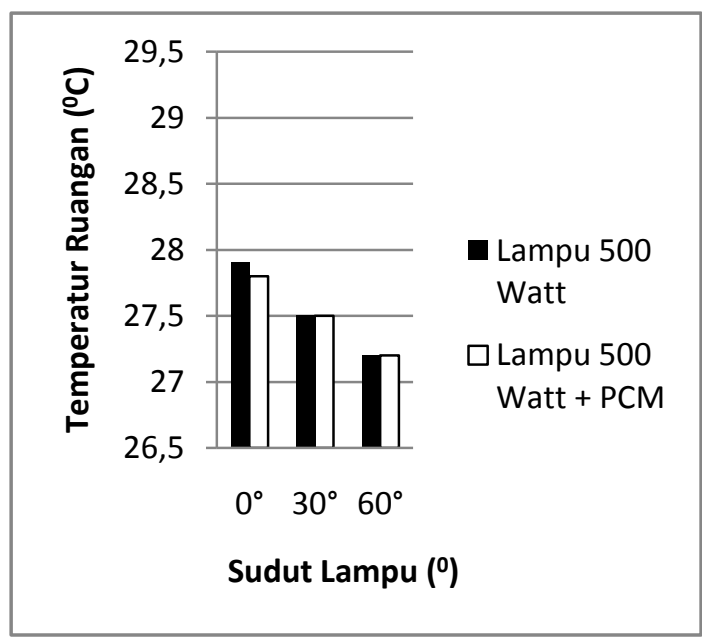

(a)

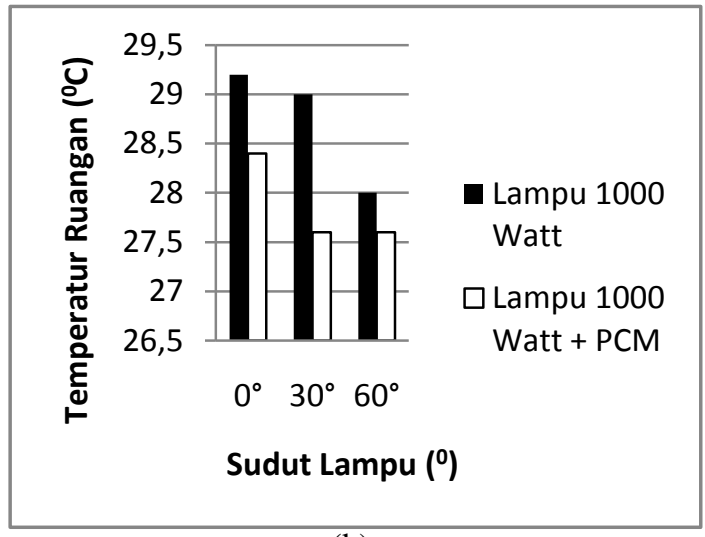

(b)

Gambar 5. (a) Diagram Hubungan antara Penggunaan PCM dengan Temperatur Ruangan Lampu 500 Watt,

(b) Diagram Hubungan antara Penggunaan PCM dengan Temperatur Ruangan Lampu 500 Watt

Berdasarkan gambar 5(a) penggunaan PCM terbukti dapat menghambat panas yang masuk ke ruangan. Pada sudut lampu $0^{0}$ lampu 500 Watt panas yang masuk lebih besar yaitu sebesar $27,9{ }^{\circ} \mathrm{C}$ dibandingkan dengan lampu 500 Watt + PCM yaitu sebesar $27,8^{\circ} \mathrm{C}$, sedangkan pada sudut lampu $30^{\circ}$ dan $60^{\circ}$ panas yang masuk sama besar yaitu masing-masing sebesar 27,5 $\mathrm{W} / \mathrm{m}^{2}$ dan $27,2 \mathrm{~W} / \mathrm{m}^{2}$. Walaupun terjadi perbedaan temperatur ruangan pada sudut lampu $0^{0}$, namun perbedaan itu tidak terlalu besar. Hal ini dikarenakan lampu 500 Watt intensitas cahayanya rendah sehingga perubahan temperatur ruangan tidak terlalu signifikan.

Berdasarkan gambar 5(b) juga terbukti bahwa penggunaan PCM dapat menghambat panas yang masuk ke ruangan. Pada diagram terlihat jelas pengaruhnya pada ketiga parameter sudut lampu yaitu $0^{\circ}, 30^{\circ}, 60^{\circ}$. Hal ini dikarenakan intensitas cahaya lampu 1000 watt relatif besar sehingga panas yang merambat masuk juga besar. Jika tidak menggunakan PCM temperatur ruangan pada sudut lampu $0^{0}$ mencapai $29,2{ }^{\circ} \mathrm{C}$, sedangkan jika menggunakan PCM temperatur ruangan sebesar $28.4{ }^{\circ} \mathrm{C}$. Perbedaan temperatur ruangan pada keduanya tidak terlalu signifikan, hal ini dikarenakan material yang digunakan untuk wadah PCM terbuat dari seng yang mempunyai nilai konduktivitas termal $116 \mathrm{~W} / \mathrm{m}^{2}$ sehinnga panas yang masuk ke ruangan juga relatif besar.

\section{SIMPULAN}

Berdasarkan hasil pengujian dan analisis pembahasan, maka dapat diambil kesimpulan sebagai berikut :

1. Perubahan temperatur ruangan dipengaruhi oleh intensitas cahaya lampu. Semakin besar intensitasnya maka semakin besar pula panas yang masuk ke ruangan.

2. Intensitas cahaya lampu terbesar dihasilkan pada sudut lampu $0^{0}$. Pada lampu $500 \mathrm{Watt}$ $\mathrm{I}_{\mathrm{r}}=311.2 \mathrm{~W} / \mathrm{m}^{2}$ dan lampu 1000 Watt $\mathrm{I}_{\mathrm{r}}=$ $600 \mathrm{~W} / \mathrm{m}^{2}$. Hal ini disebabkan karena posisi penyinaran lampu ke PV mendekati tegak lurus, dimana intensitas cahaya maksimal dihasilkan apabila posisi penyinaran lampu tegak lurus terhadap PV.

3. Laju perpindahan panas juga dipengaruhi oleh intensitas cahaya lampu. Semakin besar intensitasnya maka semakin besar pula laju perpindahan panas yang terjadi. Pada lampu 500 watt dengan $\mathrm{I}_{\mathrm{r}}=311.2 \mathrm{~W} / \mathrm{m}^{2}$ dihasilkan $\mathrm{q}=0.0132 \mathrm{~W} / \mathrm{m}^{2}$, sedangkan pada lampu 1000 watt dengan $\mathrm{I}=600 \mathrm{~W} / \mathrm{m}^{2}$ dihasilkan $\mathrm{q}=0.0341 \mathrm{~W} / \mathrm{m}^{2}$. Hasil ini lebih besar dibandingkan dengan sudut lampu $30^{\circ}$ dan $60^{\circ}$. 


\section{DAFTAR PUSTAKA}

[1] http://www.esdm.go.id/.../714-blue-printpengelolaan-energi-nasional-pen.htm, diakses tanggal 18 November 2013.

[2]http://solarenergyindonesia.com/index.php/ tahun-2014-kapasitas-terpasang-plts-2-gwdengan-menggunakan-solar-sell/, diakses tanggal 18 November 2013.

[3]Directorate or Electricity and Energy Development, (DESDM), 1997. Master plan for development of new and renewable energy,

[4]Tim Balai Sains Bangunan. 2010, Laporan Audit Energi Gedung Sumberdaya Air dan Penataan Ruang Kementerian Pekerjaan Umum. Bandung: Puslitbang Permukiman

[5]JICA Study on Energy Efficiency and Concervation Improvement in Indonesia 20072008,http://eneken.ieej.or.jp/en/data/pdf/ 491.pdf, diakses tanggal 18 November 2013

[6]Intruksi Presiden Republik Indonesia Nomor 13 tahun 2011, tentang penghematan energi danair,http://www.kemendagri.go.id/produkhukum/2011/09/19/penghematan-energi-danair

[7]Kreider, J.F., and Rabl. A. 1994. Heating and Cooling of Building. New York: Mc.GrauHill 